\title{
Ferns and lycophytes of remnants in Amazônia Maranhense, Brazil
}

\author{
Wagner Ribeiro da Silva Junior ${ }^{1} \mathbb{D}$, Alessandro Wagner Coelho Ferreira $^{1}$, Anna Luiza Ilkiu-Borges ${ }^{2} \&$ \\ Rozijane S. Fernandes ${ }^{3, *}$ (1) \\ ${ }^{1} 1$ Universidade Federal do Maranhão, Departamento de Biologia, Av. dos Portugueses, 1966, CEP 65080-805, \\ São Luís, MA, Brasil. \\ ${ }^{2}$ Museu Paraense Emílio Goeldi, Av. Perimetral, 1901-Terra Firme, CEP: 66077-830, Belém, PA, Brasil. \\ ${ }^{3}$ Universidade Federal do Maranhão, Centro de Ciências Agrárias e Ambientais, Laboratório de Sistemática \\ Vegetal, MA-222, KM 04, S/N, Boa Vista, CEP: 65500-000, Chapadinha, MA, Brasil. \\ *Corresponding author: Rozijane S. Fernandes, e-mail: rozijanef@hotmail.com
}

SILVA JUNIOR, W.R., FERREIRA, A.W.C., ILKIU-BORGES, A.L., FERNANDES, R.S. Ferns and lycophytes of remnants in Amazônia Maranhense, Brazil. Biota Neotropica 20(3): e20200972. https://doi.org/10.1590/16760611-BN-2020-0972

\begin{abstract}
This work is an inventory of ferns and lycophytes of remnants in Amazônia Maranhense. The data provided are the results of collections made from 2010-2011 and 2016-2019 in various municipalities of Maranhão in the Amazonian part of the state. Sixty-four species of ferns and lycophytes, in 36 genera and 18 families, were recorded. Of these, 24 species are new records for Maranhão and four are new records for the Northeast Region of Brazil. The most representative family was Pteridaceae ( 23 species), followed by Polypodiaceae ( 7 species). The predominant life forms were terrestrial (37 species) and epiphytic ( 15 species); the latter is the highest number of epiphytic species recorded for a fern and lycophyte inventory in Maranhão. The data support the need for collecting ferns and lycophytes in Amazônia Maranhense to better understand the flora of these groups in the state.
\end{abstract}

Keywords: Brazilian, Legal, Amazon; Amazonian, Forest, Inventory; New, record.

\section{Samambaias e Licófitas de remanescentes da Amazônia Maranhense, Brasil}

Resumo: Neste trabalho apresentamos um inventário de Samambaias e Licófitas ocorrentes em remanescentes da Amazônia Maranhense. Os dados aqui presentes são resultados de coletas entre os anos de 2010-2011 e 20162019 em vários municípios do Maranhão inseridos nesta porção amazônica do estado. Registrou-se um total de 64 espécies de Samambaias e Licófitas, distribuídos em 36 gêneros e 18 famílias. Vinte e quatro espécies são novas ocorrências para o Maranhão, com 4 destas relatadas pela primeira vez para a região Nordeste do Brasil. A família mais representativa foi Pteridaceae (23 espécies), seguida por Polypodiaceae ( 7 espécies). As formas de vida predominantes foram terrícolas com 37 espécies e epífitas com 15 espécies, sendo este número de epífitas o maior registrado em um inventário de Samambaias e Licófitas do Maranhão. Estes dados reforçam a necessidade de coletas destes grupos de plantas na Amazônia Maranhense de forma a caracterizar amplamente a flora de Samambaias e Licófitas do Maranhão.

Palavras-chave: Amazônia, Legal, Brasileira; Floresta, Amazônica; Inventário; Novas, ocorrências. 


\section{Introduction}

Maranhão is the only state in Northeast Brazil that has its western portion partially in the Brazilian Legal Amazon region, which corresponds to $24.46 \%$ of the state (Martins \& Oliveira 2011). This part of the state is influenced by the Belém Center of Endemism that extends east of the Tocantins River to Amazônia Maranhense (Almeida \& Vieira 2010). This region is known for its plant biodiversity with Amazonian characteristics (Pré-Amazônia). However, the area is strongly impacted by fires, illegal hunting and conflicts related to the extraction of wood (Almeida et al. 2010, Almeida \& Vieira 2010, Domingues \& Bermann 2012, Latorre et al. 2017). Amazônia Maranhense is $81,208.40 \mathrm{~km}^{2}$, includes 62 municipalities and, among the areas of the Brazilian Legal Amazon, has the fewest protected areas and is susceptible to a high degree of deforestation and forest fragmentation (Martins \& Oliveira 2011).

The Belém Center of Endemism, which includes the Amazônia Maranhense, is characterized mainly by Amazonian forest with diverse phytophysiognomies interspersed with waterways (Almeida \& Vieira 2010, Spinelli-Araújo 2016, Miranda et al. 2017, Rodrigues 2018), and contains high biodiversity (Rolim et al. 2011). This region is fed by the Tocantins, Gurupi and Pindaré rivers (Santos 2014) and only $17.66 \%$ of its total area is protected by two conservation units: Área de Preservação Ambiental da Baixada Maranhense and Reserva Biológica do Gurupi (REBIO Gurupi) (Silva et al. 2005, Almeida \& Vieira 2010). Despite being an integral conservation unit, REBIO Gurupi has only $23 \%$ preserved primary forest (Silva et al. 2005, Almeida \& Vieira 2010) and is one of the last fragments of protected Amazonian forested in Maranhão State.

Ferns and lycophytes are distinct and phylogenetically distant lineages (Pryer et al. 2004) that are studied together because they share ecological and morphological relationships (BFG 2018). In Brazil, 1.361 ferns and lycophytes have been recorded, of which 553 (around $40 \%$ of the total) occur in Amazonia, including 36 species that are endemic to this biome (Flora do Brasil 2020 under construction, 2019).

Published studies about ferns and lycophytes in Maranhão State are scarce, especially in the Amazonian portion where these plants are more likely to occur. The first of these studies was by Bastos \& Cutrim (1999). Since then, there have been some works that cite common species in anthropized areas (Conceição \& Ruggieri 2010, Conceição et al. 2015, Silva et al. 2017, Silva Júnior et al. 2018) and a few studies conducted in conservation units with a low sampling of species (Fernandes et al. 2007, 2010, Conceição \& Rodrigues 2010). However, recent works recorded the occurrence of new species in Amazonian regions (Salino et al. 2011), demonstrating the need for more studies in these areas.

The number of ferns and lycophytes currently recorded for Maranhão State is 81 species. Of these, 64 species occur in the Amazon biome (Flora do Brasil 2020 under construction, 2019). However, these numbers are underestimated. Thus, the objective of this study was to increase the area sampled and, consequently, the number of fern and lycophyte species recorded for areas in Amazônia Maranhense, especially REBIO Gurupi, Área de Preservação Ambiental da Baixada Maranhense, and surroundings.

\section{Material and Methods}

\section{Study area}

Amazônia Maranhense is located in the eastern portion of Maranhão

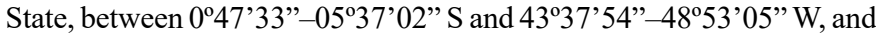

is $81,208.40 \mathrm{~km}^{2}$, or around $24.46 \%$ of the state (Martins \& Oliveira 2011). The region of Amazônia Maranhense has a hot and humid climate (type Am, at the transition limit of Aw) (Köppen 1948). The annual rainfall index varies from $1,500-2,000 \mathrm{~mm}$, but rainfall is unevenly distributed throughout the year, with a rainy season from January to June and a dry season from July to December (Golfari 1980, Jesus et al. 1986).

The vegetation of Amazônia Maranhense includes different phytophysiognomies, predominantly dense alluvial ombrophilous forest, dense lowland ombrophilous forest, dense submontane ombrophilous forest, pioneer formations influenced by rivers and lakes, pioneer formations influenced by rivers and oceans, pioneer formations influenced by oceans and secondary vegetation, such as capoeiras (Spinelli-Araújo 2016, Miranda et al. 2017, Rodrigues 2018).

\section{Data collection, herborization and identification}

The data were collected bimonthly from 2010-2011 and 2016-2019 in the municipalities of Alcântara, Boa Vista do Gurupi, Bom Jardim, Cândido Mendes, Centro Novo do Maranhão, Paço do Lumiar, Pedro do Rosário, Pinheiro, Presidente Sarney, Santa Helena, São José de Ribamar and São Luís. A map was created (Figure 1) taking into account the database of vegetation and biomes in Maranhão state (IBGE 2013). The herbarium specimens were made according to the procedures in Silva (1989) and Bridson \& Forman (1998). All of the collected material was deposited in the CCAA herbarium. Duplicates of some species were sent to the MAR and SLUI herbaria. Additionally, specimens in the following herbaria were studied: MG, CCAA MAR and SLUI, designated by the acronyms in Index Herbariorum (Thiers 2019). Species names and authors follow The International Plant Names Index (IPNI 2019).

To identify the fern and lycophyte species in the study area, a stereomicroscope, articles about the flora of the region, and taxonomic revisions of groups were used. The geographic distribution of species was verified using the sites Flora do Brasil 2020 under construction (2019) and Specieslink (2019). The taxonomic arrangement of families and genera follows PPG I (2016).

For each species, records for municipalities and voucher material are provided. The images of species were taken with a digital camera in the field and/or based on fertile parts of herbarium specimens. The photographic plates, preferentially of new occurrences for the flora of Maranhão State, were made with Photoshop ${ }^{\circledR}$ CS6 v.13.0 (Adobe Systems 2012). Comments about the environment of occurrence are based on the area where the material was collected. Life forms were determined based on Lellinger (2002) and Zuquim et al. (2008).

The following legends and abbreviations will the used along the text for identifying new occurrences: * new for Maranhão, ** new for the Northeast Region; Life form/growth: $\mathrm{AQ}=$ Aquatic, $\mathrm{EP}=$ Epiphyte, $\mathrm{HE}=$ Hemiepiphyte, $\mathrm{TE}=$ Terrestrial, $\mathrm{RP}=$ Rupicolous; Environment of occurrence: $\mathrm{SP}=$ Swamp, $\mathrm{CP}=$ Capoeira, $\mathrm{OF}=$ Open field, $\mathrm{ST}=$ Stream, $\mathrm{TFF}=$ Terra firme forest, $\mathrm{RF}=$ Riparian forest, $\mathrm{MRP}=$ Margin of riparian forest, $\mathrm{GF}=$ Gallery forest; Geographic distribution: $\mathrm{SA}=$ South America, $\mathrm{TA}=$ Tropical America, $\mathrm{PA}=$ Pantropical .

\section{Results}

\section{Diversity}

This inventory identified 64 species of lycophytes and ferns. These species are distributed in 36 genera and 18 families. Most of the species 


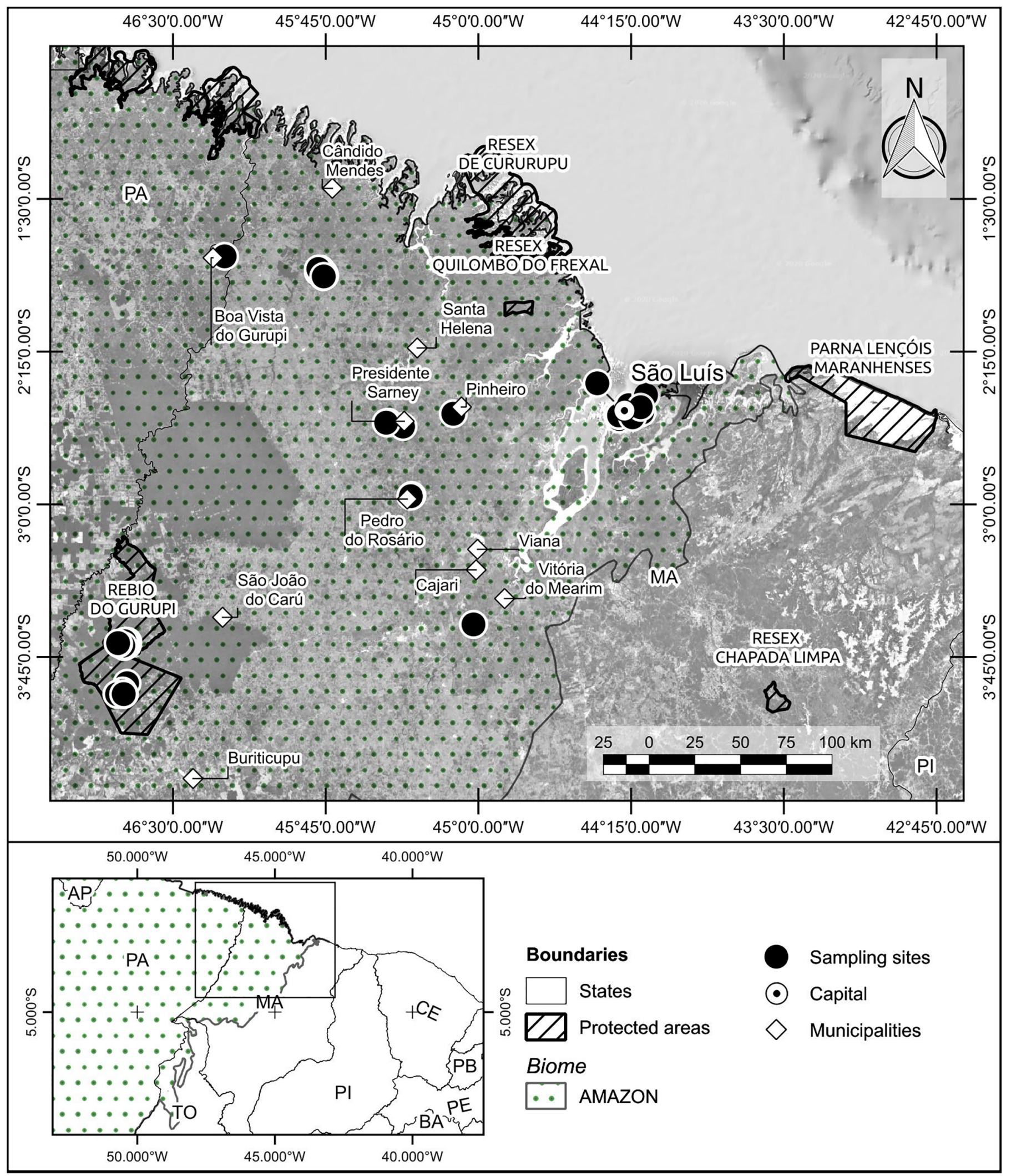

Figure 1. Map of the study area. Sampling sites in black. 
recorded (62 spp., 97\%) are ferns, which are distributed in 34 genera and 16 families. The only lycophytes collected were Palhinhaea cernua (L.) Franco \& Vasc. and Selaginella sp. Among the identified species, 24 (36\% of the total) are new records for Maranhão State, of which four are new records for the Northeast Region of Brazil.

The life form with the higher number of species was terrestrial with 35 species (54.7\% of the species), followed by epiphyte with 14 species (21.9\%), hemiepiphyte with $7(10.9 \%)$, aquatic with four species $(6.2 \%)$, rupicolous with three species $(4.7 \%)$, and one species presented more than one life form: epiphyte and terrestrial (1.6\%).

\section{List of family, species, comments and material examined}

\section{Lycophytes}

Lycopodiaceae

Palhinhaea cernua (L.) Franco \& Vasc., Bol. Soc. Brot., sér. 2. 41: 25. 1967.

This species is found in open fields near swamps and along forest margins and grows from buds on its prostrate branches. Life form/growth: TE. Environment of occurrence: OF. Geographic distribution: PA.

Selected specimens examined: Brazil. Maranhão: Cândido Mendes, Fazenda Sete Irmãos, Brejo próximo a açude, 14.X.2017, Ferreira, A.W.C. \& Silva Junior, W.R. 62 (CCAA). Paço do Lumiar, Praia do Araçagi, 15.XII.2017, Silva Junior, W.R. \& Ferreira, A.W.C. 195 (SLUI).

\section{Selaginellaceae}

Selaginella sp. Figure $2 \mathrm{G}$

This species was observed growing in a streambed in partial shade. Few individuals were fertile. Life form/growth: TE. Environment of occurrence: TFF.

Material examined: Brazil. Maranhão: Cândido Mendes, Fazenda Sete Irmãos, 26.X.2019, Silva Junior, W.R. \& Ferreira, A.W.C. 154 (CCAA). Idem, Silva Junior, W.R. \& Ferreira, A.W.C. 155 (SLUI).

\section{Ferns}

\section{Aspleniaceae}

*Asplenium salicifolium L., Sp. Pl. 2: 1080. 1753. Figure 3A-B

This species was only observed in the dry season, growing as an epiphyte in the canopy and on lower parts of tree trunks. Life form/ growth: EP. Environment of occurrence: TFF. Geographic distribution: TA.

Material examined: Brazil. Maranhão: Cândido Mendes, Fazenda Sete Irmãos, margem de curso do rio Macaxeira, 27.X.2019, Silva Junior, W.R. \& Ferreira, A.W.C. 193 (CCAA). Idem, Silva Junior, W.R. \& Ferreira, A.W.C. 194 (SLUI).

\section{Asplenium serratum L., Sp. P1. 2: 1079. 1753. Figure 2E-F}

The specimens of this species in Amazônia Maranhense were epiphytes in the understory and clearings, mainly on the base of large trees near streams. Life form/growth: EP. Environment of occurrence: TFF. Geographic distribution: TA.

Material examined: Brazil. Maranhão: Cândido Mendes, Fazenda Sete Irmãos, trilha densa, 13.X.2017, Silva Junior, W.R. \& Ferreira, A.W.C. 57 (CCAA). Idem, Silva Junior, W.R. \& Ferreira, A.W.C. 56 (SLUI).

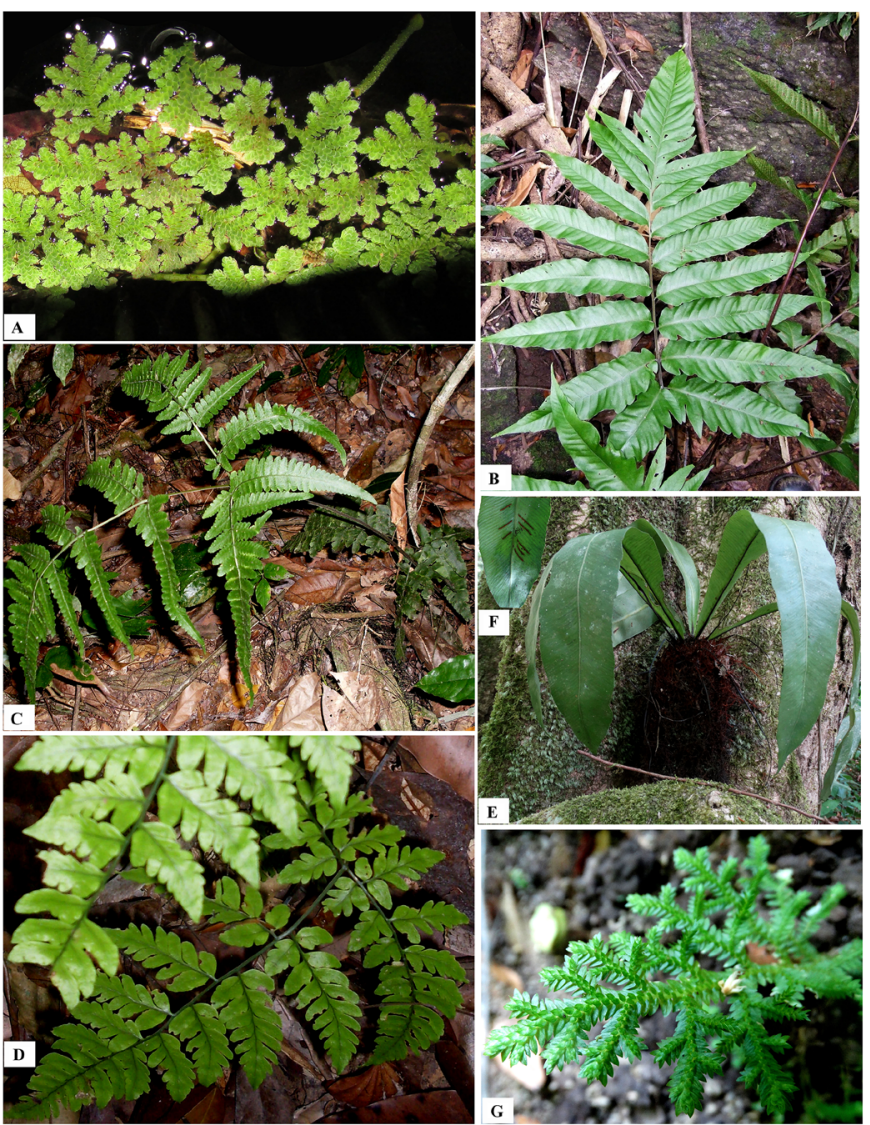

Figure 2. A. Azolla filiculoides Lam. Habit. B. Tectaria incisa Cav. Habit. C. Triplophyllum dicksonioides (Fée) Holttum. Habit. D. Triplophyllum glabrum J. Prado \& R.C. Moran. Habit. E-F. Asplenium serratum L. E. Habit. F. Elongate sori on the frond. G. Selaginella sp. Habit.

\section{Blechnaceae}

Telmatoblechnum serrulatum (Rich.) Perrie, D.J. Ohlsen \& Brownsey, Taxon 63 (4): 755. 2014.

Usually found on the borders of sunny swamps, humid forests and the margins of roads in flooded areas. It commonly grows vegetatively over large extensions and often occurs together with Palhinhaea cernua and Meniscium serratum. Life form/growth: TE. Environment of occurrence: SP. Geographic distribution: TA.

Selected specimens examined: Brazil. Maranhão: Bom Jardim, KM 100 Igarapé Gurupi, 31.VIII.2010, Fernandes, R.S. 575 (MG). Centro Novo do Maranhão, REBIO Gurupi - Norte, 06.IX.2010, Fernandes, R.S. 636 (MG). Presidente Sarney, margem da estrada para Presidente Sarney, 20.VII.2017, Silva Junior, W.R. \& Ferreira, A.W.C. 25 (CCAA). Paço do Lumiar, Praia do Araçagi, brejo ao lado de um mangue, 15.XII.2017, Silva Junior, W.R. \& Ferreira, A.W.C. 196 (SLUI). Cândido Mendes, Fazenda Sete Irmãos, brejo próximo a base abandonada da fazenda, 26.X.2019, Silva Junior, W.R. \& Ferreira, A.W.C. 176 (CCAA).

\section{Cyatheaceae}

Cyathea delgadii Sternb., Vers. Fl. Vorwelt 1: 47. 1820. Figure 4A

Collected along water courses, often in the shade, varied from 1.5 $\mathrm{m}$ to $2.5 \mathrm{~m}$ tall, and was frequently associated with Mauritia flexuosa L. Occasionally, it grows on the borders of forests and anthropized areas; in these areas the individuals are smaller. Life form/growth: TE. Environment of occurrence: MRP. Geographic distribution: SA. 


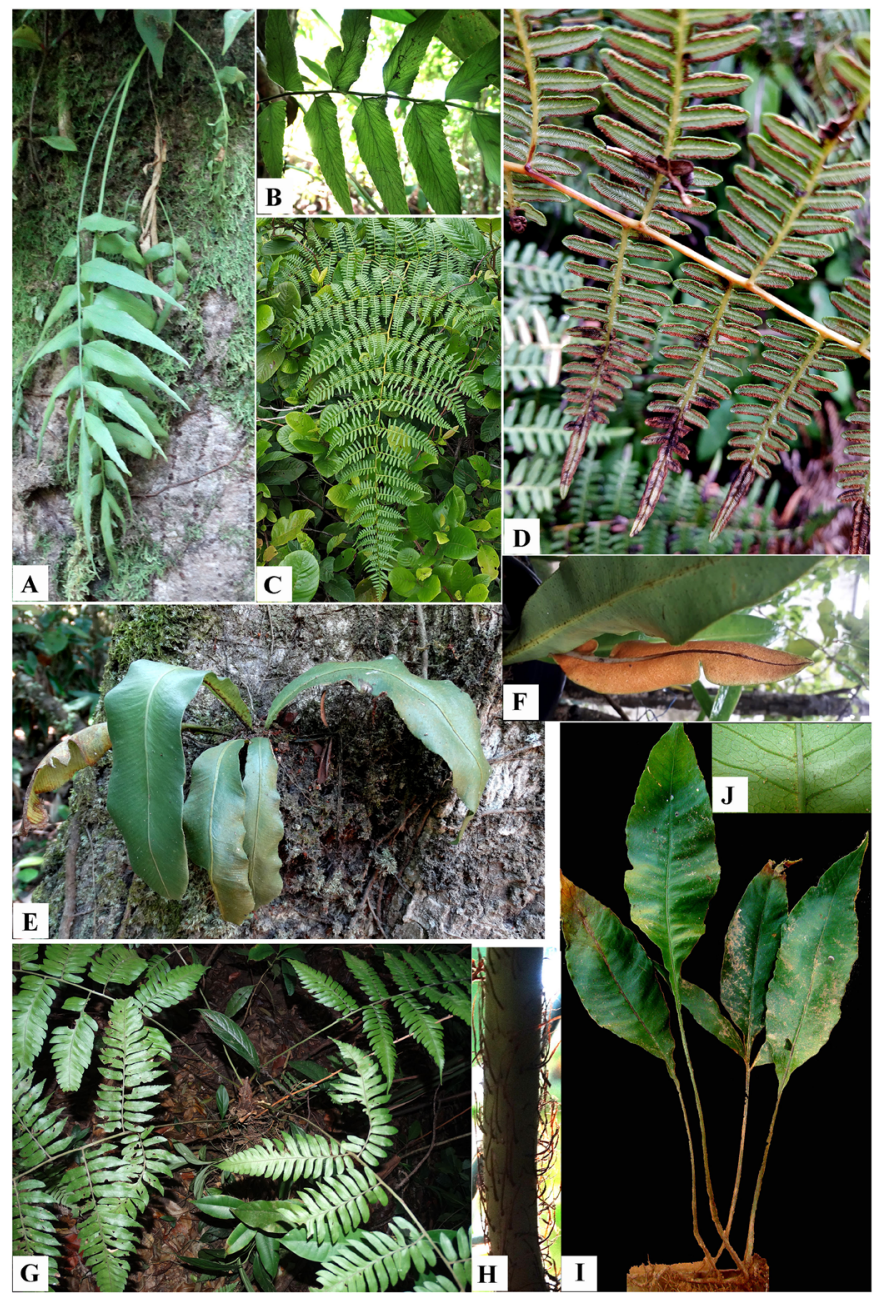

Figure 3. New occurrences for Amazônia Maranhense. A-B. Asplenium salicifolium L. A. Habit. B. Abaxial surface of the pinnules. C-D. Pteridium caudatum (L.) Maxon. C. Lamina. D. Abaxial surface of the pinnules showing the sori. E-F. Elaphoglossum luridum (Fée) Christ. E. Habit. F. Fertile frond G-H. Polybotrya caudata Kunze. G. Habit. H. Petiole with scales. I-J. Mickelia nicotianifolia (Sw.) R.C.Moran \& Labiak \& Sundue. I. Habit. J. Detail of abaxial surface showing anastomosing veins.

Material examined: Brazil. Maranhão: Pinheiro, Buritizal com corredor de água, proximidades do povoado de Purão dos Pirrós, 22.VIII.2018, Silva Junior, W.R. \& Ferreira, A.W.C. 42 (CCAA 580). Idem, Silva Junior, W.R. \& Ferreira, A.W.C. 41 (SLUI).

Cyathea microdonta (Desv.) Domin, Pteridophyta 263. 1929.

This species is less frequent than Cyathea delgadii and occurs in the interior of forests and along margins of riparian forests. The individuals tend to be a little smaller than those of $C$. delgadii and grow scattered in the area. Life form/growth: TE. Environment of occurrence: MRP. Geographic distribution: TA.

Selected specimens examined: Brazil. Maranhão: Centro Novo do Maranhão, REBIO Gurupi-Norte, 04.IX.2010, Fernandes, R.S. 603 (MG).

\section{Dennstaedtiaceae}

**Pteridium caudatum (L.) Maxon, Proc. U. S. Natl. Mus. 23 (1226): 631. 1901. Figure 3C-D

This species was collected on the margins of highways and edges of forests, in areas with high anthropic impact. It grows in sunny areas and forms large populations. Life form/growth: TE. Environment of occurrence: OF. Geographic distribution: TA.

Material examined: Brazil. Maranhão: Boa Vista do Gurupi, Margem da BR-316, 04.III.2019, Silva Junior, W.R. \& Ferreira, A.W.C. 130 (CCAA). Idem, Silva Junior, W.R. \& Ferreira, A.W.C. 197 (SLUI).

\section{Dryopteridaceae}

Ctenitis refulgens (Klotzsch ex Mett.) C. Chr. ex Vareschi, Flora de Venezuela 1: 404. 1969.

Collected near streams and small water courses in forests, in lower, shaded places where water runs off. Life form/growth: TE. Environment of occurrence: TFF. Geographic distribution: TA.

Material examined: Brazil. Maranhão: Bom Jardim, REBIO Gurupi - Sul, 30.VIII.2010, Fernandes, R.S. 567 (MG).

**Elaphoglossum luridum (Fée) Christ, Neue Denkschr. Allg. Schweiz. Ges. Gesammten Naturwiss. 36(1): 33. 1899. Figure 3E-F

Epiphyte on the trunks of large trees on the margins of streams and on fallen trunks. It was also observed that in the dry season this species can lose its leaves, leaving only the rhizome that sprouts new leaves during the rainy season. Life form/growth: EP. Environment of occurrence: TFF. Geographic distribution: SA.

Selected specimens examined: Brazil. Maranhão: Pedro do Rosário, Igarapé da Ponte, 19.VIII.2017, Silva Junior, W.R. 24 (CCAA). Cândido Mendes, Fazenda Sete Irmãos, 13.X.2017, Silva Junior, W.R. \& Ferreira, A.W.C. 60 (SLUI).

**Mickelia nicotianifolia (Sw.) R.C. Moran \& Labiak \& Sundue, Brittonia 62 (4): 347. 2010. Figure 3I-J

Hemiepiphyte on trees on the margins of water courses. It prefers shady areas and mostly grows in the understory of forests. Life form/growth: HE. Environment of occurrence: MRP. Geographic distribution: SA.

Material examined: Brazil. Maranhão: Centro Novo do Maranhão, REBIO Gurupi - Norte, 06.IX.2010, Fernandes, R.S. 635 (MG).

*Polybotrya caudata Kunze, Linnaea 9(1): 23. 1834. Figure 3G-H

Hemiepiphyte near populations of Lomariopsis japurensis. It is more frequent in areas near water courses but can occasionally occur in dryer areas in the forest understory. Life form/growth: HE. Environment of occurrence: MRP. Geographic distribution: TA.

Material examined: Brazil. Maranhão: Cândido Mendes, Fazenda Sete Irmãos, igarapé próximo a uma base da fazenda, 26.X.2019, Silva Junior, W.R \& Ferreira, A.W.C. 166 (CCAA). Idem, Silva Junior, W.R \& Ferreira, A.W.C. 167 (SLUI).

\section{Hymenophyllaceae}

*Didymoglossum angustifrons Fée, Mém. Foug. 11: 113, t. 28, f. 5. 1866. Figure 4B-D

Epiphyte on the bark of phorophyte stems near streams and in dry areas. It was only observed in very shady areas in the forest understory. Life form/growth: EP. Environment of occurrence: TFF. Geographic distribution: TA.

Material examined: Brazil. Maranhão: Cândido Mendes, Fazenda Sete Irmãos, trilha próxima a igarapé com açaizal, 26.X.2019, Silva Junior, W.R. \& Ferreira, A.W.C. 169 (CCAA). Idem, Silva Junior, W.R. \& Ferreira, A.W.C. 170 (SLUI). 


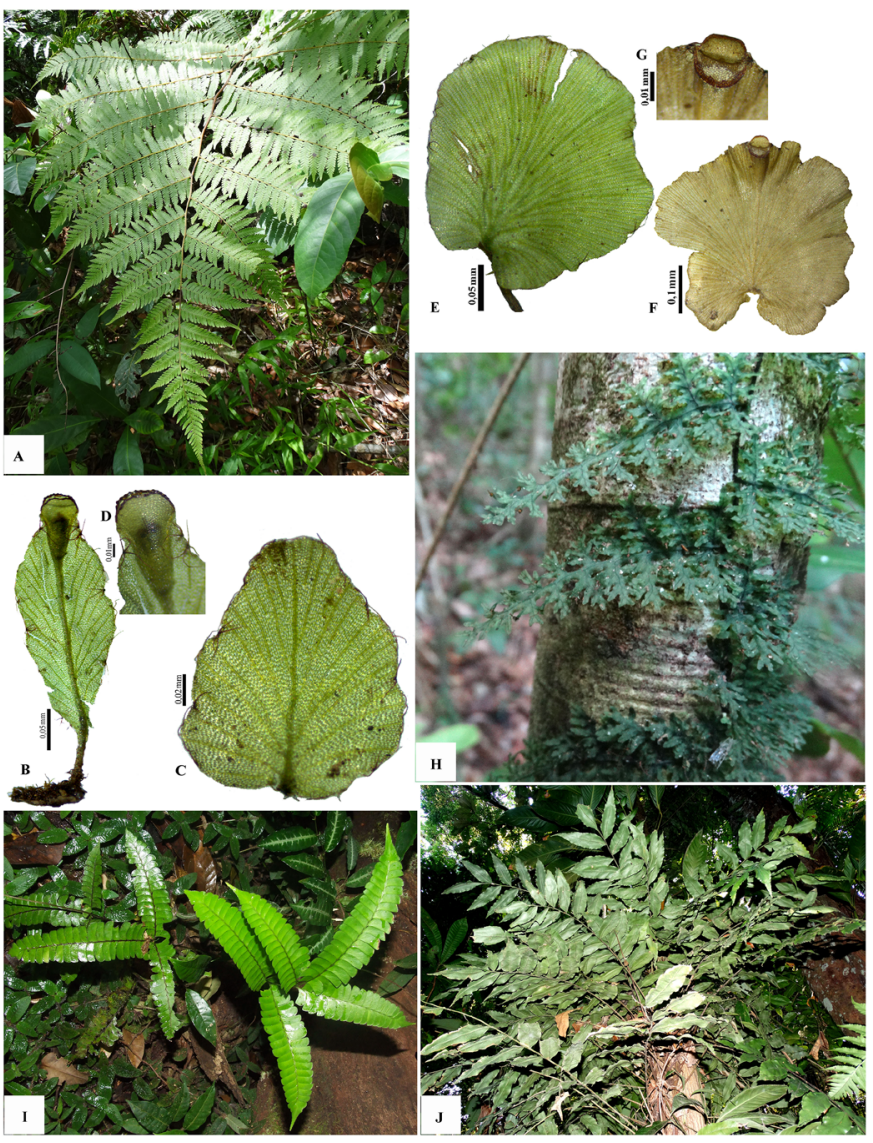

Figure 4. A. Cyathea delgadii Sternb. Pinnae. B-D. Didymoglossum angustifrons Fée. B. Fertile frond. C. Sterile frond. D. Indusium detail showing a single row of dark border cells. E-G. Didymoglossum punctatum (Poir.) Desv. E. Sterile frond. F. Fertile frond. G. Indusium detail showing a double row of dark border cells. H. Trichomanes pedicellatum Desv. Habit. I. Lindsaea lancea (L.) Bedd. var. lancea. Habit. J. Lomariopsis japurensis (Mart.) J.Sm. Habit.

*Didymoglossum punctatum (Poir.) Desv., Mém. Soc. Linn. Paris 6(3): 330. 1827. Figure 4E-G

Grows in the study area as an epiphyte on the bark of phorophyte trunks in dry areas inside forests. It was only observed in shady areas in the understory. Life form/growth: EP. Environment of occurrence: TFF. Geographic distribution: TA.

Material examined: Brazil. Maranhão: Cândido Mendes, Fazenda Sete Irmãos, 26.X.2019, Silva Junior, W.R. \& Ferreira, A.W.C. 143 (CCAA).

*Trichomanes pedicellatum Desv., Ges. Naturf. Freunde Berlin Mag. 5: 328. 1811. Figure 4H

Hemiepiphytic on the bark of phorophyte trunks, exclusively in very shady areas in the understory inside terra firme forests. Life form/growth: HE. Environment of occurrence: TFF. Geographic distribution: TA.

Selected specimens examined: Brazil. Maranhão: Cândido Mendes, Fazenda Sete Irmãos, sub-bosque de trilha aberta, 26.X.2019, Silva Junior, W.R. \& Ferreira, A.W.C. 159 (CCAA).

Trichomanes pinnatum Hedw., Fil. Gen. Sp. 17. t. 4. fig. 1 \& a, b. 1799 .

Terrestrial and generally occurs in the shade on runoff banks of water courses and in dryer areas. Life form/growth: TE. Environment of occurrence: CP. Geographic distribution: TA.
Selected specimens examined: Brazil. Maranhão: Bom Jardim, REBIO Gurupi - Sul, 31.VIII.2010, Fernandes, R.S. 573 (MG). Centro Novo do Maranhão, REBIO Gurupi - Norte, 03.IX.2010, Fernandes, R.S. 589 (MG). Cândido Mendes, Fazenda Sete Irmãos, 14.X.2017, Silva Junior, W.R. \& Ferreira, A.W.C. 73 (MAR). Idem, 26.X.2019, Silva Junior, W.R. \& Ferreira, A.W.C. 157 (CCAA).

Trichomanes vittaria DC. ex Poir., E.C., Botanique 8: 65. 1808.

Terrestrial on the margins of water, such as lakes and streams, in shadier places or rarely in areas with a lot of light. Life form/growth: TE. Environment of occurrence: TFF. Geographic distribution: SA.

Material examined: Brazil. Maranhão: Centro Novo do Maranhão, REBIO Gurupi - Norte, 03.IX.2010, Fernandes, R.S. 590 (MG).

\section{Lindsaeaceae}

Lindsaea lancea (L.) Bedd. var. lancea, Suppl. Ferns S. Ind. 6. 1876. Figure 4I

Terrestrial in partially shaded areas on the margins of streams. It does not form large populations and individuals grow sparsely in forest clearings. Life form/growth: TE. Environment of occurrence: RF. Geographic distribution: TA.

Material examined: Brazil. Maranhão: Centro Novo do Maranhão, REBIO Gurupi - Norte, 07.IX.2010, Fernandes, R.S. 641 (MG). Cândido Mendes, Fazenda Sete Irmãos, 13.X.2017, Silva Junior, W.R. \& Ferreira, A.W.C. 51 (CCAA). Idem, Silva Junior, W.R. \& Ferreira, A.W.C. 52 (SLUI).

\section{Lomariopsidaceae}

*Lomariopsis japurensis (Mart.) J. Sm., Hist. Fil. 140. 1875. Figure 4J

Collected in the understory of closed vegetation as a hemepiphyte on the trunks of phorophytes on the margins of riparian forest. It can occur with Polybotrya caudata. Life form/growth: HE. Environment of occurrence: MRP. Geographic distribution: TA.

Material examined: Brazil. Maranhão: Centro Novo do Maranhão, REBIO Gurupi - Norte, 05.IX.2010, Fernandes, R.S. 611 (MG). Cândido Mendes, Fazenda Sete Irmãos, 26.X.2019, Silva Junior, W.R. \& Ferreira, A.W.C. 148 (CCAA). Idem, Silva Junior, W.R. \& Ferreira, A.W.C. 149 (SLUI).

Lomariopsis prieuriana Fée, Mém. Foug., 2: 66. 1845.

Hemiepiphyte on the trunks of trees in the understory of the forest, generally in flooded areas near the margin of riparian forest. Occasionally, it can be found together with Lomariopsis japurensis. Life form/growth: HE. Environment of occurrence: MRP. Geographic distribution: TA.

Selected specimens examined: Brazil. Maranhão: Centro Novo do Maranhão, REBIO Gurupi - Norte, 03.IX.2010, Fernandes, R.S. $582(\mathrm{MG})$.

\section{Lygodiaceae}

Lygodium venustum Sw., J. Bot. (Schrader) 1801 (2): 303.1803.

Most frequent in degraded areas. It was collected as a scandent plant in anthropized and more preserved areas, generally with Lygodium volubile Sw. Life form/growth: HE. Environment of occurrence: OF. Geographic distribution: TA. 
Selected specimens examined: Brazil. Maranhão: Bom Jardim, REBIO Gurupi - Sul, 30.VIII.2010, Fernandes, R.S. 558 (MG). Bom Jardim, REBIO Gurupi - Norte, 07.IX.2010, Fernandes, R.S. 640 (MG). São José de Ribamar, Trilha de mata aberta, APA do Itapiracó, 12.V.2018, Silva Junior, W.R. \& Ferreira, A.W.C. 90 (MAR). São Luís, Cidade Universitária, Universidade Federal do Maranhão - Vila Bacanga, trilha nos arredores de uma lagoa, 08.VI.2018, Silva Junior, W.R. \& Ferreira, A.W.C. 92 (CCAA). Boa Vista do Gurupi, Margem da BR-316, 04.III.2019, Silva Junior, W.R. \& Ferreira, A.W.C. 132 (MAR). Arari, Margem da BR-222, 02.III.2019, Silva Junior, W.R. \& Ferreira, A.W.C. 133 (MAR).

Lygodium volubile Sw., J. Bot. (Schrader) 1801 (2): 304.1803.

This species is less frequent than Lygodium venustum and was found in shadier areas in the interior of gallery forest. It is scandent on vegetation and forms large coverings. Life form/growth: HE. Environment of occurrence: OF. Geographic distribution: TA.

Material examined: Brazil. Maranhão: Centro Novo do Maranhão, REBIO Gurupi - Norte, 04.IX.2010, Fernandes, R.S. 606 (MG). São Luís, Fragmento de mata - Cohafuma, 26.X.2016, Silva Junior, W.R. \& Ferreira, A.W.C. 003 (CCAA).

\section{Marsileaceae}

Marsilea polycarpa Hook. \& Grev., Icon. Filic. 2: 160. 1830.

Collected on the margins of the Turiaçu River where there is seasonal inundation, in the dry season, where there were puddles; it formed large populations. It also grows in anthropized areas near sewage streams and on the margins of roads. Life form/growth: AQ. Environment of occurrence: SP. Geographic distribution: TA.

Selected specimens examined: Brazil. Maranhão: Presidente Sarney, Lagoas próximas a margem de inundação do Rio Turiaçu, 20.VIII.2017, Silva Junior, W.R. 27 (MAR). São José de Ribamar, APA do Itapiracó, beira da estrada próxima a um esgoto, 12.V.2018, Silva Junior, W.R. \& Ferreira, A.W.C. 86 (CCAA).

\section{Nephrolepidaceae}

Nephrolepis biserrata (Sw.) Schott, Gen. Fil. Pl. t. 3. 1834. Figure 5A

Epiphyte on the leaf sheaths of the babaçu (Attalea speciosa Mart. ex Spreng.) plam. Less often, it is terrestrial in more humid areas, such as swamps and on lake margins. Life form/growth: EP, TE. Environment of occurrence: CP, OF. Geographic distribution: PA.

Material examined: Brazil. Maranhão: Centro Novo do Maranhão, REBIO Gurupi - Norte, 03.IX.2010, Fernandes, R.S. 592 (MG). Paço do Lumiar, Praia do Araçagi, terreno baldio, 15.XII.2017, Silva Junior, W.R. \& Ferreira, A.W.C. 84 (CCAA). Idem, Silva Junior, W.R. \& Ferreira, A.W.C. 202 (SLUI).

Nephrolepis brownii (Desv.) Hovenkamp \& Miyam., Blumea 50 (2): 293. 2005.

Terrestrial near swampy regions and small water courses. Occasionally, it occurs with Nephrolepis biserrata, Palhinhaea cernua, Cyclosorus interruptus (Willd.) H. Ito and Telmatoblechnum serrulatum (Rich.) Perrie, D.J. Ohlsen \& Brownsey. Life form/growth: TE. Environment of occurrence: OF. Geographic distribution: PA.

Material examined: Brazil. Maranhão: Centro Novo do Maranhão, REBIO Gurupi - Norte, 06.IX.2010, Fernandes, R.S. 639 (MG).
Cândido Mendes, Fazenda Sete Irmãos, próximo ao açude, 14.X.2017, Silva Junior, W.R. \& Ferreira, A.W.C 66 (CCAA). Idem, Silva Junior, W.R. \& Ferreira, A.W.C 67 (SLUI).

\section{Polypodiaceae}

Campyloneurum phyllitidis (L.) C. Presl, Tent. Pterid. 190, t. 7 f. 18-20. 1836. Figure 5B

Epiphyte on the trunks of phorophytes, always near water courses where there is a lot of light. Life form/growth: EP. Environment of occurrence: GF. Geographic distribution: TA.

Material examined: Brazil. Maranhão: Centro Novo do Maranhão, REBIO Gurupi - Norte, 04.IX.2010, Fernandes, R.S. 602 (MG 238062). Cândido Mendes, Fazenda Sete Irmãos, curso seco do rio Macaxeira, 27.X.2019, Silva Junior, W.R. \& Ferreira, A.W.C. 190 (CCAA). Idem, Silva Junior, W.R. \& Ferreira, A.W.C. 191 (SLUI).

*Microgramma lycopodioides (L.) Copel., Gen. Fil. 185. 1947. Figure 5C

Epiphyte in the interior of forests, especially in humid places, such as branches above streams. This species rarely occurs in anthropic areas. When present in these areas it is often on Mangifera indica $\mathrm{L}$. Life form/growth: EP. Environment of occurrence: ST. Geographic distribution: TA.

Selected specimens examined: Brazil. Maranhão: Pedro do Rosário, Curso d'água no Igarapé da Ponte, 19.VIII.2017, Silva Junior, W.R. \& Ferreira, A.W.C. 18 (CCAA). Cândido Mendes, Fazenda Sete Irmãos, trecho próximo ao rio Macaxeira, 27.X.2019, Silva Junior, W.R. \& Ferreira, A.W.C. 189 (SLUI). Boa Vista do Gurupi, BR-316, 04.III.2019, Silva Junior, W.R. \& Ferreira, A.W.C. 203 (SLUI).

*Microgramma persicariifolia (Schrad.) C. Presl, Tent. Pterid. 214. 1836. Figure 5D

It is uncommon in the study area. It is an epiphyte in the canopy of phorophytes and can grow until it reaches the soil. It usually occurs on the margins of streams with Microgramma lycopodioides and Microgramma reptans (Cav.) A.R.Sm. Life form/growth: EP. Environment of occurrence: ST. Geographic distribution: TA.

Selected specimens examined: Brazil. Maranhão: Pedro do Rosário, Margens do Igarapé da Ponte, 19.VIII.2017, Silva Junior, W.R. \& Ferreira, A.W.C. 20 (CCAA). Presidente Sarney, Região do Três Furos, 20.VIII.2017, Silva Junior, W.R. \& Ferreira, A.W.C. 120 (CCAA). Cândido Mendes, Fazenda Sete Irmãos, 26.X.2019, Silva Junior, W.R. \& Ferreira, A.W.C. 153 (SLUI).

*Microgramma reptans (Cav.) A.R.Sm., Proc. Calif. Acad. Sci. ser. 4, 40: 230. 1975. Figure 5E

This species grows on trunks and in the tops of phorophytes in shady places in the understory, usually near water courses. It is uncommon and restricted to less disturbed areas. Life form/growth: EP. Environment of occurrence: ST. Geographic distribution: TA.

Selected specimens examined: Brazil. Maranhão: Pedro do Rosário, Sub-bosque do Igarapé da Ponte, 19.VIII.2017, Silva Junior, W.R. \& Ferreira, A.W.C. 22 (CCAA). Santa Helena, proximidades do Rio Turiaçu, 25.X.2019, Silva Junior, W.R. \& Ferreira, A.W.C. 135 (SLUI). Cândido Mendes, Fazenda Sete Irmãos, trilha próxima ao rio Macaxeira, 27.X.2019, Silva Junior, W.R. \& Ferreira, A.W.C. 183 (CCAA). 


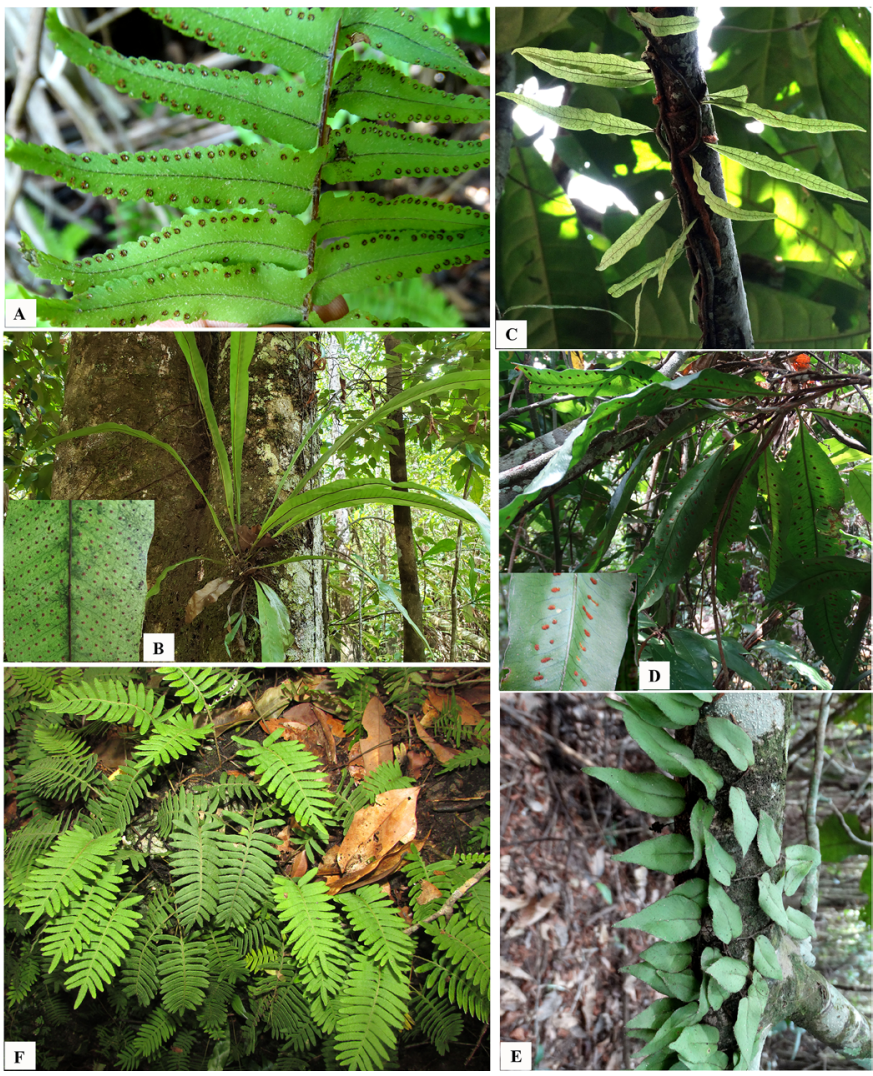

Figure 5. A. Nephrolepis biserrata (Sw.) Schott. Sori detail on abaxial surface B. Campyloneurum phyllitidis (L.) C. Presl. Habit and detail of anastomosing veins and sori. C. Microgramma lycopodioides (L.) Copel. Habit. D. Microgramma persicariifolia (Schrad.) C.Presl. Habit and elongate sori on the frond. E. Microgramma reptans (Cav.) A.R.Sm. Habit. F. Pleopeltis burchellii (Baker) Hickey \& Sprunt ex A.R.Sm. Habit.

Phlebodium aureum (L.) J.Sm., J. Bot. (Hooker) 4: 591841.

Epiphyte on the babaçu (Attalea speciosa Mart. ex Spreng.) palm, both in sunny and shady environments. Life form/growth: EP. Environment of occurrence: OF. Geographic distribution: TA.

Material examined: Brazil. Maranhão: São José de Ribamar, APA do Itapiracó, Babaçual próximo a quadra de basquete, 12.V.2017, Silva Junior, W.R. \& Ferreira, A.W.C. 89 (CCAA). Cândido Mendes, Fazenda Sete Irmãos, 27.X.2019, Silva Junior, W.R. \& Ferreira, A.W.C. 180 (CCAA)

*Pleopeltis burchellii (Baker) Hickey \& Sprunt ex A.R.Sm., Phytotaxa 354 (1): 53. 2018. Figure 5F

This species occurs in the canopy of trees over $10 \mathrm{~m}$ tall. During the rainy season it has unfurled and fertile fronds, while during the dry season the fronds dehydrate and become furled. It grows in places with high humidity, such as near streams, lakes and other water courses. Life form/growth: EP. Environment of occurrence: ST. Geographic distribution: SA.

Material examined: Brazil. Maranhão: Centro Novo do Maranhão, REBIO Gurupi - Norte, 23.II.2011, Fernandes, R.S. 733 (MG). Pedro do Rosário, Igarapé da Ponte, 22.IX.2017, Silva Junior, W.R. \& Ferreira, A.W.C. 43 (CCAA). Idem, Silva Junior, W.R. \& Ferreira, A.W.C. 121 (SLUI).

\section{Pteridaceae}

Acrostichum aureum L., Sp. Pl. 2: 1069. 1753.

Grows in swamps influenced by mangroves, in sunny areas in saline soil that is periodically inundated by brackish water. The individuals do not form aggregates. Life form/growth: TE. Environment of occurrence: SP. Geographic distribution: TA.

Material examined: Brazil. Maranhão: Paço do Lumiar, Praia do Araçagi, Borda de um mangue, 15.XII.2017, Silva Junior, W.R. \& Ferreira, A.W.C. 79 (CCAA 2160). Idem, Silva Junior, W.R. \& Ferreira, A.W.C. 204 (SLUI).

Acrostichum danaeifolium Langsd. \& Fisch., Pl. Voy. Russes Monde 5, t. 1. 1810

It is common in the study area and occurs in more preserved and anthropized areas. It grows in swamps and sunny areas on the margins of lakes, rivers and streams, and forms large populations of aggregated individuals. Life form/growth: TE. Environment of occurrence: SP. Geographic distribution: TA.

Selected specimens examined: Brazil. Maranhão: Bom Jardim, KM 100 Igarapé Gurupi, 31.VIII.2010, Fernandes, R.S. 574 (MG). São Luís, Fragmento de mata - Cohafuma, 26.X.2016, Silva Junior, W.R. \& Ferreira, A.W.C. 02 (SLUI). Paço do Lumiar, Brejo próximo a um mangue, Praia do Araçagi, 15.XII.2017, Silva Junior, W.R. \& Ferreira, A.W.C. 77 (CCAA). São Luís, Canal de escoamento para lagoa, Cidade Universitária, Universidade Federal do Maranhão Vila Bacanga, 08.VI.2018, Silva Junior, W.R. \& Ferreira, A.W.C. 95 (CCAA). Cândido Mendes, Fazenda Sete Irmãos, brejo próximo a base abandonada da Fazenda, 27.X.2019, Silva Junior, W.R. \& Ferreira, A.W.C. 174 (CCAA)

*Adiantum argutum Splitg., Tijdschr. voor Natuurl. Gesch. en Physiol. [Leiden] 7: 427. 1840. Figure 6A

Occurs in shady areas, in the forest understory, on the margins of streams and on banks near water courses. It forms large populations that cover the soil. Life form/growth: TE. Environment of occurrence: GF, ST. Geographic distribution: SA.

Selected specimens examined: Brazil. Maranhão: Pedro do Rosário, Trilha densa próxima a um curso d'água - Igarapé da Ponte, 19.VIII.2017, Silva Junior, W.R. 23 (CCAA). São Luís, próximo a tucunzal - Tirirical, 08.VI.2018, Silva Junior, W.R. \& Ferreira, A.W.C. 102 (SLUI).

*Adiantum cajennense Willd. ex Klotzsch, Linnaea 18: 552. 1845. Figure 6B

This species grows in dryer environments and in the interior of forests in more humid areas, such as the margins of streams. Life form/growth: TE. Environment of occurrence: TFF. Geographic distribution: TA

Selected specimens examined: Brazil. Maranhão: Bom Jardim, REBIO Gurupi - Sul, 30.VIII.2010, Fernandes, R.S. 562 (MG). Centro Novo do Maranhão, REBIO Gurupi-Norte, 03.IX.2010, Fernandes, R.S. 579 (MG).

**Adiantum cinnamomeum Lellinger \& J. Prado, Amer. Fern J. 91 (1): 1-8. 2001.

Grows in areas away from water courses, in the forest understory in sunny environments, as separate individuals. Life form/growth: TE. Environment of occurrence: TFF. Geographic distribution: TA. 
Material examined: Brazil. Maranhão: Centro Novo do Maranhão, REBIO Gurupi - Norte, 05.IX.2010, Fernandes, R.S. 613 (MG).

Adiantum deflectens Mart., Ic. P1. Crypt. 94. 1834.

It is very common in the study area and occurs in anthropized and preserved areas. It grows on rocks or on banks near water courses or on sidewalks and walls in urban areas. Life form/growth: RP. Environment of occurrence: OF, GF. Geographic distribution: TA.

Selected specimens examined: Brazil. Maranhão: Paço do Lumiar, Praia do Araçagi, Beirada de um córrego, 15.XII.2017, Silva Junior, W.R. \& Ferreira, A.W.C. 76 (CCAA). São Luís, escoamento do esgoto - Tirirical, 08.VI.2018, Silva Junior, W.R. \& Ferreira, A.W.C. 100 (CCAA).

*Adiantum dolosum Kunze, Linnaea 21 (2): 219. 1848. Figure 6C

This species grows in shady environments in the understory of gallery and terra firme forests. It prefers banks and slopes near water courses. Occasionally, it forms aggregates of individuals, but is usually sparse. Life form/growth: TE. Environment of occurrence: GF, TFF. Geographic distribution: SA.

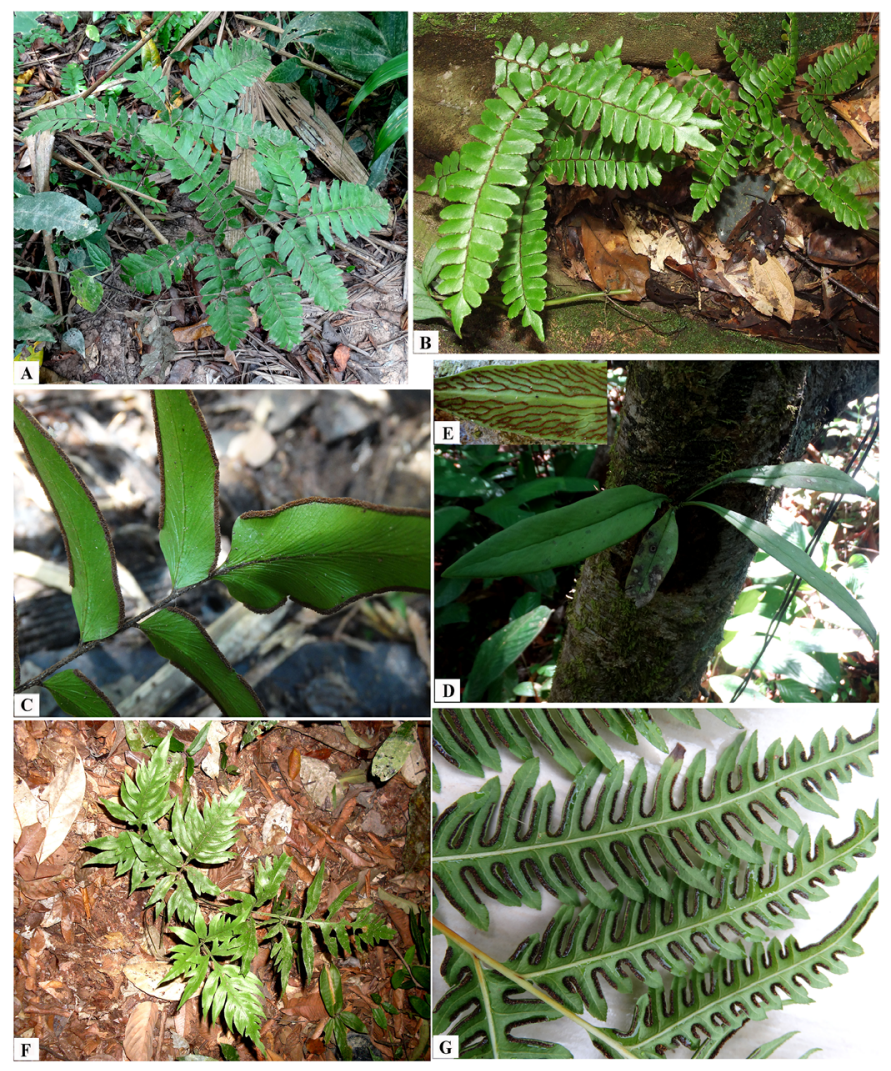

Figure 6. A. Adiantum argutum Splitg. Habit. B. Adiantum cajennense Willd. ex Klotzsch. Habit. C. Adiantum dolosum Kunze. Detail of linear sori on the abaxial surface of the pinnules. D-E. Polytaenium guayanense (Hieron.) Alston. D. Habit. E. Sori along the veins. F. Pteris denticulata var. tristicula (Raddi) J. Prado. Habit. G. Pteris tripartita Sw. Interrupted sori on the pinnules.

Selected specimens examined: Brazil. Maranhão: Bom Jardim, REBIO Gurupi - Sul, 28.VIII.2010, Fernandes, R.S. 551 (MG). Centro Novo do Maranhão, REBIO Gurupi - Norte, 03.IX.2010, Fernandes, R.S. 581 (MG). São Luís, Solo argiloso próximo a um barranco -
Tirirical, 08.VI.2018, Silva Junior, W.R. \& Ferreira, A.W.C. 107 (CCAA). Cândido Mendes, Fazenda Sete Irmãos, 26.X.2019, Silva Junior, W.R. \& Ferreira, A.W.C. 146 (CCAA).

Adiantum glaucescens Klotzsch, Linnaea 18: 552. 1844.

Grows in the interior of terra firme forests in shady places. It is uncommon and restricted to denser vegetation. Life form/growth: TE. Environment of occurrence: TFF. Geographic distribution: SA.

Selected specimens examined: Brazil. Maranhão: Centro Novo do Maranhão, REBIO Gurupi - Norte, 03.IX.2010, Fernandes, R.S. $587(\mathrm{MG})$.

Adiantum latifolium Lam., Encycl. M., Botan. 1: 43. 1783.

Grows in humid, shady areas near the margins of streams and banks of water courses. Life form/growth: TE. Environment of occurrence: GF. Geographic distribution: TA.

Material examined: Brazil. Maranhão: Centro Novo do Maranhão, REBIO Gurupi - Norte, 23.II.2011, Fernandes, R.S. 731 (MG).

\section{Adiantum lucidum (Cav.) Sw., Syn. Fil. 121. 1806.}

Grows in terra firme forest in shadier areas with rocky soil. Individuals are sparse and far from water courses. Life form/ growth: TE. Environment of occurrence: TFF. Geographic distribution: SA.

Selected specimens examined: Brazil. Maranhão: Bom Jardim, REBIO Gurupi - Sul, 29.VIII.2010, Fernandes, R.S. 553 (MG).

Adiantum obliquum Willd., Sp. P1., ed. 4, 5 (1): 429. 1810.

Terrestrial on banks near water courses. Individuals are sparse or rarely form large populations. Life form/growth: TE. Environment of occurrence: TFF. Geographic distribution: TA.

Material examined: Brazil. Maranhão: Bom Jardim, REBIO Gurupi - Sul, Bom Jardim, 30.VIII.2010, Fernandes, R.S. 571 (MG). Centro Novo do Maranhão, REBIO Gurupi - Norte, 06.IX.2010, Fernandes, R.S. 633 (MG).

Adiantum paraense Hieron., Hedwigia 48: 233. Tab. 11, 10. 1909.

This species occurs in the interior of terra firme forests on the margins of water courses in areas with light. Individuals grow separately and do not form large populations. Life form/growth: TE. Environment of occurrence: TFF. Geographic distribution: SA.

Selected specimens examined: Brazil. Maranhão: Centro Novo do Maranhão, REBIO Gurupi - Norte, 03.IX.2010, Fernandes, R.S. $586(\mathrm{MG})$.

\section{Adiantum petiolatum Desv., Berl. Mag. 5. 326. 1811.}

Occurs on banks where rainwater flows and banks with clayey soil with rocks. It grows in sunny and very shady environments, and usually forms large populations. Life form/growth: TE. Environment of occurrence: TFF. Geographic distribution: TA.

Selected specimens examined: Brazil. Maranhão: Centro Novo do Maranhão, REBIO Gurupi - Norte, 04.IX.2010, Fernandes, R.S. 607 (MG 238067). Cândido Mendes, Fazenda Sete Irmãos, trilha aberta, 14.X.2017, Silva Junior, W.R. \& Ferreira, A.W.C. 68 (MAR). São Luís, próximo rio Bacanga, 15.VI.2018, Silva Junior, W.R. \& Ferreira, A.W.C. 113 (CCAA). 
Adiantum pulverulentum L., Sp. P1. 2: 1096. 1753.

Occurs in sunny and shady environments in terra firme forests. It grows isolated on clayey soil covered with rocks, often with populations of Adiantum petiolatum. Life form/growth: TE. Environment of occurrence: GF. Geographic distribution: TA.

Material examined: Brazil. Maranhão: Bom Jardim, REBIO Gurupi - Sul, 30.VIII.2010, Fernandes, R.S. 568 (MG). São Luís, próximo ao Rio Bacanga - Vila Embratel, Silva Junior, W.R. \& Ferreira, A.W.C. 110 (CCAA). Idem, Silva Junior, W.R. \& Ferreira, A.W.C. 111 (SLUI).

Adiantum terminatum Kunze ex Miq., Inst. Versl. Meded. Kon. Naderl. Inst. Wetensch. 1842: 187. 1843.

This species occurs along trail margins and in denser vegetation in terra firme forest. It grows isolated in dry locations in environments with light and shade. Life form/growth: TE. Environment of occurrence: GF. Geographic distribution: TA.

Selected specimens examined: Brazil. Maranhão: Centro Novo do Maranhão, REBIO Gurupi - Norte, 03.IX.2010, Fernandes, R.S. 594 (MG). Cândido Mendes, Fazenda Sete Irmãos, 13.X.2017, Silva Junior, W.R. \& Ferreira, A.W.C. 44 (CCAA 576). São Luís, à beira da estrada Tirirical, 08.VI.2018, Silva Junior, W.R. \& Ferreira, A.W.C. 105 (SLUI).

Ananthacorus angustifolius (Sw.) Underw. \& Maxon, Contr. U.S. Natl. Herb. 10: 487. 1908.

Epiphyte in the canopy of trees on the margins of streams, stretches of rivers and other water courses, in very shady areas. Occasionally, it occurs with Vittaria lineata (L.) Sm. Life form/growth: EP. Environment of occurrence: ST. Geographic distribution: TA.

Material examined: Brazil. Maranhão: Santa Helena, Curso de escoamento do Rio Turiaçu, 20.VIII.2017, Silva Junior, W.R. \& Ferreira, A.W.C. 39 (MAR). Cândido Mendes, Fazenda Sete Irmãos, margem de uma lagoa, 14.X.2017, Silva Junior, R.S. \& Ferreira, A.W.C. 71 (MAR).

Ceratopteris thalictroides (L.) Brongn., Bull. Sci. Soc. Philom. Paris 8: 186. 1821.

Fixed aquatic plant in muddy soil near lakes and swamps. The individuals grow evenly distributed and often occur with Salvinia auriculata and Marsilea polycarpa. Life form/growth: AQ. Environment of occurrence: SP. Geographic distribution: PA.

Material examined: Brazil. Maranhão: Presidente Sarney, Região de poças lamacentas próximo ao Rio Turiaçu - região dos Três Furo, 20.VIII.2017, Silva Junior, W.R. 37 (MAR). Paço do Lumiar, Proximidades do Projeto Marrom, Praia do Araçagi, 15.XII.2017, Silva Junior, W.R. \& Ferreira, A.W.C. 75 (CCAA).

Pityrogramma calomelanos (L.) Link var. calomelanos, Handbuch 3: 20.1833.

Rupicolous plant on rocks near swamps and occasionally near the mangrove area. Individuals were sparse and found in partial shade. Life form/growth: RP. Environment of occurrence: OF. Geographic distribution: TA.

Material examined: Brazil. Maranhão: Centro Novo do Maranhão, REBIO Gurupi - Norte, 06.IX.2010, Fernandes, R.S. 629 (MG). Paço do Lumiar, Praia do Araçagi, terreno abandonado, 15.XII.2017, Silva Junior, W.R. \& Ferreira, A.W.C. 78 (CCAA). Cândido Mendes, Fazenda Sete Irmãos, próximo a um brejo, 26.X.2019, Silva Junior, W.R. \& Ferreira, A.W.C. 172 (CCAA).
*Polytaenium guayanense (Hieron.) Alston, Bull. Misc. Inform. Kew 1932 (7): 314. 1932. Figure 6D-E

Epiphyte on the trunks of phorophytes in dense forest in dryer areas. Few individuals were observed and most of these were growing in very shady areas. Life form/growth: EP. Environment of occurrence: TFF. Geographic distribution: TA.

Material examined: Brazil. Maranhão: Cândido Mendes, Fazenda Sete Irmãos, trilha fechada, 13.X.2017, Silva Junior, W.R. \& Ferreira, A.W.C. 53 (CCAA).

*Pteris denticulata var. tristicula (Raddi) J. Prado, Amer. Fern J. 83: 131. 1993. Figure 6F

Terrestrial in the understory of open forests with soil covered by rocks. It is also found in dryer areas as a rupicolous plant. Life form/growth: TE. Environment of occurrence: TFF. Geographic distribution: SA.

Material examined: Brazil. Maranhão: Bom Jardim, REBIO Gurupi - Sul, 30.VIII.2010, Fernandes, R.S. 561 (MG).

Pteris tripartita Sw., J. Bot. 1800 (2): 67. 1801. Figure 6G

Collected in polluted places, such as streams and swamps near flowing sewage. It usually grows in shady places, or rarely in full sun. Life form/growth: TE. Environment of occurrence: GF, SP. Geographic distribution: PA.

Material examined: Brazil. Maranhão: São José de Ribamar, Maiobinha, 11.I.2017, Silva Junior, W.R. \& Ferreira, A.W.C. 004 (MAR). São luís, Buritizal próximo a estrada-Cohafuma, 15.VI.2018, Silva Junior, W.R. \& Ferreira, A.W.C. 119 (MAR).

*Pteris vittata L., Sp. Pl. 2: 1074. 1753.

Rupicolous in anthropic areas near water channels, in cracks in residential walls, and in roof gutters. Life form/growth: RP. Environment of occurrence: OF. Geographic distribution: PA.

Material examined: Brazil. Maranhão: Paço do Lumiar, Praia do Araçagi, terreno abandonado, 15.XII.2017, Silva Junior, W.R. \& Ferreira, A.W.C. 74 (CCAA). Idem, Silva Junior, W.R. \& Ferreira, A.W.C. 206 (SLUI).

Vittaria lineata (L.) Sm., Mém. Acad. Roy. Sci. (Turin) 5: 421. t. 9. f. 5. 1793.

This species is uncommon in the study area and is an epiphyte, in well-preserved areas with high humidity, on tree trunks near water courses and on the roots of the babaçu (Attalea speciosa Mart. ex Spreng) palm. When $V$. lineata occurs in low light its fronds are longer compared to when it grows in sunny places. Life form/growth: EP. Environment of occurrence: ST, TFF. Geographic distribution: TA.

Material examined: Brazil. Maranhão: Santa Helena, curso seco do rio Turiaçu, 20.VII.2017, Silva Junior, W.R. \& Ferreira, A.W.C. 40 (MAR). São José de Ribamar, Trilha de área desmatada, APA do Itapiracó, 12.V.2018, Silva Junior, W.R. \& Ferreira, A.W.C. 91 (MAR). São Luís, Tucunzal próxima a estrada para rodoviária - Tirirical, 08.VI.2018, Silva Junior, W.R. \& Ferreira, A.W.C. 99 (CCAA).

\section{Salviniaceae}

*Azolla filiculoides Lam., E. M., Botanique 1 (1): 343.1783. Figure 2A 
This species is not very common in the study area and is restricted to remote areas. It is usually found in environments with other small aquatic plants, such as Lemna valdiviana Phil., Wolffiella lingulata (Hegelm.) Hegelm. and the aquatic fern Salvinia auriculata Aubl. Life form/growth: AQ. Environment of occurrence: ST. Geographic distribution: PA.

Material examined: Brazil. Maranhão: Igarapé do Meio, Trecho sobre ponte acima do Igarapé Puraquéu, 06.III.2019, Silva Junior, W.R. \& Ferreira, A.W.C. 128 (CCAA).

Salvinia auriculata Aubl., Hist. P1. Guiane 2. 969 t. 367. 1775. Bak. Hdb. 136. NPfl. 402.

Floating aquatic plant on the margins of rivers, streams, lakes and other water courses with little or no current. It grows in water exposed to full sun and in shady places and is common in anthropized areas. Occasionally, it can be found with Azolla filiculoides. Life form/growth: AQ. Environment of occurrence: ST. Geographic distribution: TA.

Material examined: Brazil. Maranhão: Bom Jardim, KM 100 Igarapé Gurupi, 31.VIII.2010, Fernandes, R.S. 577 (MG). Igarapé do Meio, Trecho sobre ponte acima do Igarapé Puraquéu, 06.III.2019, Silva Junior, W.R. \& Ferreira, A.W.C. 129 (CCAA). Santa Helena, trecho do Rio Turiaçu, 25.X.2019, Silva Junior, W.R. \& Ferreira, A.W.C. 136 (SLUI). Presidente Sarney, próximo ao rio Turiaçu, 25.X.2019, Silva Junior, W.R. \& Ferreira, A.W.C. 138 (SLUI).

\section{Tectariaceae}

*Tectaria incisa Cav., Descr. P1. 249. 1802. Figure 2B

Terrestrial in the study area and grows in soil on rocky outcrops. It is most common on the margins of water courses but can also occur in dryer areas. Life form/growth: TE. Environment of occurrence: TFF. Geographic distribution: TA.

Material examined: Brazil. Maranhão: Centro Novo do Maranhão, REBIO Gurupi - Norte, 04.IX.2010, Fernandes, R.S. 605 (MG).

*Triplophyllum dicksonioides (Fée) Holttum, Kew Bull. 41 (2): 257. 1986. Figure 2C

This species forms large populations in the study area, mainly in the understory of forests. It grows in terra firme forest near banks and water courses in non-inundated areas. Life form/growth: TE. Environment of occurrence: TFF. Geographic distribution: SA.

Selected specimens examined: Brazil. Maranhão: Bom Jardim, REBIO Gurupi - Sul, 30.VIII.2010, Fernandes, R.S. 564 (MG). Centro Novo do Maranhão, REBIO Gurupi - Norte, 03.IX.2010, Fernandes, R.S. 596 (MG).

Triplophyllum funestum (Kunze) Holttum, Kew Bull. 41 (2): 255. 1986

Grows sparsely on banks where water flows. It is not a common species in this region and is restricted to the understory in closed vegetation in forests. Life form/growth: TE. Environment of occurrence: TFF. Geographic distribution: TA.

Selected specimens examined: Brazil. Maranhão: Bom Jardim, REBIO Gurupi - Sul, 29.VIII.2010, Fernandes, R.S. 556 (MG). Centro Novo do Maranhão, REBIO Gurupi - Norte, 03.IX.2010, Fernandes, R.S. 580 (MG). Cândido Mendes, Fazenda Sete Irmãos, escoamento d'água, 13.X.2017, Silva Junior, W.R. \& Ferreira, A.W.C. 48 (CCAA). Idem, Silva Junior, W.R. \& Ferreira, A.W.C. 49 (SLUI).

**Triplophyllum glabrum J. Prado \& R.C. Moran, Brittonia 60 (2): 121. 2008. Figure 2D

This species grows mostly in the understory of terra firme forest. It can occur with T. funestum. Life form/growth: TE. Environment of occurrence: TFF. Geographic distribution: SA.

Selected specimens examined: Brazil. Maranhão: Bom Jardim, REBIO Gurupi - Sul, 30.VIII.2010, Fernandes, R.S. 565 (MG). Centro Novo do Maranhão, REBIO Gurupi - Norte, 03.IX.2010, Fernandes, R.S. 597 (MG).

\section{Thelypteridaceae}

Cyclosorus interruptus (Willd.) H. Ito, Bot. Mag. 51: 714. 1937.

Grows in swampy areas on the sides of roads and borders of forests, usually in sunny areas. It forms large populations, covering the surface of the swamp, due to its vegetative propagation. It occurs with Telmatoblechnum serrulatum and Meniscium serratum. Life form/growth: TE. Environment of occurrence: SP. Geographic distribution: PA.

Material examined: Brazil. Maranhão: Bom Jardim, KM 100 do Igarapé Gurupi, 31.VIII.2010, Fernandes, R.S. 576 (MG). Centro Novo do Maranhão, REBIO Gurupi - Norte, 06.IX.2010, Fernandes, R.S. 637 (MG). Cândido Mendes, Fazenda Sete Irmãos, nas proximidades de um açude, 14.X.2017, Silva Junior, W.R. \& Ferreira, A.W.C. 72 (CCAA). Paço do Lumiar, Praia do Araçagi, ao lado do mangue, 15.XII.2017, Silva Junior, W.R. \& Ferreira, A.W.C. 80 (CCAA). São Luís, Margem de uma lagoa na Universidade Federal do Maranhão - Vila Bacanga, Silva Junior, W.R. \& Ferreira, A.W.C. 97 (CCAA).

Goniopteris amazonica (Salino \& R.S. Fernandes) Salino \& T.E. Almeida, PhytoKeys 57: 36. 2015.

This species is terrestrial and, usually grows on slopes along streams, in the understory of forest and along trails in the interior of forest. Life form/growth: TE. Environment of occurrence: TFF. Geographic distribution: TA.

Material examined: Brazil. Maranhão: Centro Novo do Maranhão, REBIO Gurupi - Norte, 6.IX.2010, R. S. Fernandes 630 631, 632 (MG).

Meniscium hostmannii (Klotzsch) R.S. Fern. \& Salino, Phytotaxa 184 (1): 8. 2014.

Terrestrial in swamps and shallow water courses, mainly in sunny places. It is usually sparse and grows with populations of Meniscium serratum. Life form/growth: TE. Environment of occurrence: SP. Geographic distribution: SA.

Material examined: Brazil. Maranhão: São Luís, Cohafuma, 15.VI.2018, Silva Junior, W.R. 118 (CCAA).

Meniscium serratum Cav., Descr. Pl. (Cavanilles) 548. 1803.

Rupicolous and mainly grows in swampy, open, sunny environments. In anthropic areas, it can be found in canals with sewage and rain water, often with Cyclosorus interruptus. Life form/growth: TE. Environment of occurrence: SP. Geographic distribution: TA.

Selected specimens examined: Brazil. Maranhão: Centro Novo do Maranhão, REBIO Gurupi - Norte, 04.IX.2010, Fernandes, R.S. 604 (MG). São Luís, Brejo as margens de um esgoto - Cohafuma, 
15.VI.2018, Silva Junior, W.R. \& Ferreira, A.W.C. 117 (CCAA). Cândido Mendes, Fazenda Sete Irmãos, brejo próximo a base abandonada da fazenda, 26.X.2019, Silva Junior, W.R. \& Ferreira, A.W.C. 207 (SLUI).

\section{Discussion}

The species collected in this inventory represents around $12 \%$ of the species cataloged in the Brazilian Amazon (Flora do Brasil 2020 under construction, 2019). All of the species identified in this study have records for the Amazon biome, similar to the fern and lycophyte flora of Pará State, which is on the western border of Maranhão, especially along the Gurupi River (Silva \& Rosário 2008, Maciel \& Pietrobom 2010a, 2010b, Fernandes et al. 2012, Góes-Neto \& Pietrobom, 2012, 2014, Moura et al. 2016, Almeida et al. 2017).

The geographic distribution of species in the study area is predominantly Tropical American or South American, which is consistent with species in the Amazon region of Bolívia (Kessler \& Smith 2017). There are also pantropical and invasive species, such as Pteris tripartita and Pteris vittata, which must be controlled so they do not damage native vegetation (Silva Junior et al. 2018).

The family with the most species was Pteridaceae ( 23 species), which has diversified life forms and occurs in various habitats, as found in the study area. This family has a wide geographic distribution, is most diverse in the tropics (Maciel \& Pietrobom 2010a) and is the fern family with the most species in Maranhão (Flora do Brasil 2020 under construction, 2019). The genus Adiantum, in the Pteridaceae, had the highest number of recorded species ( 15 species), of which four are new records for Maranhão and one (Adiantum cinnamomeum) is a new record for the Northeast Region of Brazil (Flora do Brasil 2020 under construction, 2019).

The second most representative family was Polypodiaceae with seven species, of which four are reported for the first time for Maranhão State (Flora do Brasil 2020 under construction, 2019). In inventories conducted in Maranhão State, Polypodiaceae is not cited or is one of the less representative families. This is because all the studies have been conducted in areas of Cerrado where the diversity of epiphytic species is lower (Conceição \& Rodrigues 2010, Silva et al. 2017). It is noteworthy that the present inventory reported the highest number of epiphytic fern species for Maranhão (15 species), which is probably due to an increase in fieldwork in the Amazonian portion. The presence of epiphytic representatives in the study area, such as the families Hymenophyllaceae (two species), Polypodiaceae (six species) and Pteridaceae (three species), highlights the potential of these forest fragments to shelter epiphytic species, despite from constant anthropic pressures (Almeida \& Vieira 2010).

Although the fern and lycophyte flora of the region of the study area is very similar to that of Pará State ( $92 \%$ species in common) (Flora do Brasil 2020 under construction 2019), probably due to the influence of the Belém Center of Endemism (Almeida \& Vieira 2010), in the study area we also observed species in common with the Brazilian Cerrado, since there is an ecotonal zone between Amazonia and this biome in Maranhão. Examples of species in both Brazilian Amazonia and Cerrado are the following: Adiantum deflectens, Azolla filiculoides, Campyloneurum phyllitidis, Cyathea microdonta, Cyclosorus interruptus, Lindsaea lancea var. lancea, Lygodium venustum, L. volubile, Marsilea polycarpa, Meniscium hostmannii, M. serratum, Microgramma persicariifolia, Nephrolepis biserrata, Palhinhaea cernua, Phlebodium decumanum, Pityrogramma calomelanos var. calomelanos, Pleopeltis burchellii, Pteris denticulata var. denticulata, Telmatoblechnum serrulatum, Trichomanes pinnatum and Salvinia auriculata (Silva \& Rosário 2008, Arantes et al. 2010, Maciel \& Pietrobom 2010a, 2010b, Góes-Neto \& Pietrobom 2014, Miranda \& Schwartsburd 2016, Moura et al. 2016, Øllgaard \& Windisch 2016, Flora do Brasil 2020 under construction 2019).

The first record of Nephrolepis brownii for Maranhão lacks a voucher (Maciel 2016), but the species was confirmed and collected during our fieldwork.

The 24 species cited for the first time for Maranhão in this study also occur in other states in the Brazilian Legal Amazon (Maciel \& Pietrobom 2010a, 2010b, Sampaio et al. 2015, Almeida et al. 2017, Prado et al. 2017). This region is suffering from constant loss in vegetation cover due to anthropic activities, especially in Maranhão within the "arc of deforestation," such as in REBIO Gurupi (Almeida \& Vieira 2010). The importance of these remnant forests has become evident since, despite the forest fragmentation, they still contain species that usually occur in undisturbed forests, for example, Adiantum argutum, Elaphoglossum luridum, Microgramma lycopodioides, M. persicariifolia, M. reptans and Polytaenium guayanense (Maciel \& Pietrobom 2010a, 2010b, Sampaio et al. 2015, Almeida et al. 2017, Prado et al. 2017, Salino et al. 2018). This reinforces the need to preserve these areas of forest in Maranhão, since these species have not been recorded in the Cerrado in the state.

Based on recent surveys of ferns and lycophytes in Amazon (Costa \& Pietrobom 2007, Salino et al. 2018), a higher number of species was expected in the study area. Due to the Amazonian influence, the number of new occurrences for Maranhão is high and corresponds to an increase of $29.7 \%$ in relation to the 81 species currently recognized for the state (Flora do Brasil 2020 under construction 2019). Our results highlight the lack of collections of these plants in Maranhão, especially in Amazônia Maranhense.

\section{Acknowledgments}

The authors are grateful to the following for the logistical or financial support: Adão Pontarollo and his family for permission to enter the study area; Francisco Ribeiro for the help with fieldwork; the Maranhão herbarium (MAR) and CCAA herbarium at the Federal University of Maranhão, for providing assistance while processing specimens; and FAPEMA for the research funding awarded to the last author (Edital Universal, 9033/2015). We also thank Dr. Lana Sylvestre for the identification of Asplenium salicifolium; the Secretaria Estadual do Meio Ambiente do Maranhão (SEMA) for the authorization to collect (process 16276/2019); the Project Perda de Biodiversidade nos Centros de Endemismo do Arco do Desmatamento ("Loss of Biodiversity in the Centers of Endemism within the Scope of Deforestation"), from Museu Paraense Emílio Goeldi (MPEG), and Empresa Brasileira de Pesquisa Agropecuária/Centro de Pesquisa Agropecuária do Trópico Úmido (Embrapa/CPATU), under the auspices of the Instituto Nacional de Ciência e Tecnologia (INCT, National Institute of Science and Technology) project Biodiversidade e Uso da Terra na Amazônia ("Biodiversity and Land Use in the Amazon"), coordinated by Dr. Ima Célia Guimarães Vieira (MPEG). 


\section{Author Contributions}

Wagner Ribeiro da Silva Junior: collected and photographed the plants, identified the plants, revised herbarium collections, writing the text.

Alessandro Wagner Coelho Ferreira: collected and photographed the plants, identified some species, writing the text.

Anna Luiza Ilkiu-Borges: writing and revising the text.

Rozijane S. Fernandes: collected and photographed the plants, identified the plants, writing and revising the text.

\section{Conflicts of Interest}

The authors declare that they have no conflict of interest related to the publication of this manuscript.

\section{References}

ADOBE SYSTEMS. 2012. Photoshop CS6. https://www.adobe.com/ (last access on 16/11/2019).

ALMEIDA, C.A., VALERIANO, D.M., ESCADA, M.I.S. \& RENNÓ, C.D. 2010. Estimativa de área de vegetação secundária na Amazônia Legal Brasileira. Acta Amazônica. 40(2): 289-302.

ALMEIDA, A.S. \& VIEIRA, I.C.G. 2010. Centro de Endemismo Belém: Status da vegetação remanescente e desafios para a conservação da biodiversidade e restauração ecológica. Revista de Estudos Universitários. 36(3): 95-111.

ALMEIDA, T.E., SOUSA, D.C.S., COSTA, E.C. \& SALINO, A. 2017. Flora das cangas da Serra dos Carajás, Pará, Brasil: Polypodiaceae. Rodriguésia. 68(3):871-880

ARANTES, A.A., PRADO, J. \& RANAL, M.A. 2010. Polypodiaceae e Pteridaceae da Estação Ecológica do Panga, Uberlândia, Estado de Minas Gerais, Brasil. Revista Brasileira de Botânica. 33(1): 167-183.

BASTOS, C.C.C. \& CUTRIM, M.V.J. 1999. Pteridoflora da Reserva Florestal do Sacavém, São Luís - Maranhão. Boletim do Museu Paraense Emílio Goeldi, série Botânica. 15(1): 3-37.

BFG. 2018. Brazilian Flora 2020: Innovation and collaboration to meet Target 1 of the Global Strategy for Plant Conservation (GSPC). Rodriguésia. 69(4): 1513-1527.

BRIDSON, D. \& FORMAN, L. 1998. International Herbarium Handbook. Royal Botanic Gardens, Kew, England.

CONCEIÇÃO, G.M. \& RODRIGUES, M.S. 2010. Pteridófitas do Parque Estadual do Mirador, Maranhão, Brasil. Cadernos de Geociências, $n^{\circ}$ 7. p.47-53.

CONCEIÇÃO, G.M. \& RUGGIERI, A.C. 2010. Pteridófitas do município de Tufilândia, estado do Maranhão, Brasil. Pesquisa em Foco. 18(1):59-68

CONCEIÇÃO, G.M., PAULA ZÁRATE, E.L., RUGGIERI, A.C., SILVA, E.O. \& SILVA, M.F. 2015. Pteridoflora e seus aspectos ecológicos no município de Timon, Maranhão, Brasil. Brazilian Geographical Journal: Geosciences and Humanities research médium. 6(1):74-81.

COSTA, J.M. \& PIETROBOM, M.R. 2007. Pteridófitas (Lycophyta e Monilophyta) da Ilha de Mosqueiro, município de Belém, estado do Pará, Brasil. Bol. Mus. Para. Emílio Goeldi. 2(3):45-55.

DOMINGUES, M.S. \& BERMANN, C.O. 2012. Arco de reflorestamento na Amazônia: da pecuária à soja. Ambiente \& Sociedade. 15(2):1-22.

FERNANDES, R.S., G.M. CONCEIÇÃO, E.S. BRITO \& E.L. PAULAZÁRATE, 2007. Diversidade Florística de Pteridófitas da Área de Preservação Ambiental do Inhamum, Caxias, Maranhão, Brasil. Revista Brasileira de Biociências. 5(2): 411-413.

FERNANDES, R.S.; CONCEIÇÃO, G.M.; COSTA, J.M.; PAULA-ZÁRATE, E.L., 2010. Samambaias e licófitas do município de Caxias, Maranhão, Brasil. Bol. Mus. Para. Emílio Goeldi. Cienc. Nat., Belém. 5(3): 345-356.

FERNANDES, R.S., MACIEL, S. \& PIETROBOM, M.R. 2012. Licófitas e monilófitas das Unidades de Conservação da Usina Hidroelétrica - UHE de Tucuruí, Pará, Brasil. Hoehnea. 39(2):247-285.

Flora do Brasil 2020 em construção. http://floradobrasil.jbrj.gov.br/ (last access on 18/04/2019).
GOLFARI, L. 1980. Zoneamento ecológico para reflorestamento da área de influência da Serra de Carajás. Revista da Companhia Vale do Rio Doce. 1(2):3-18.

GÓES-NETO, L.A.A. \& PIETROBOM, M.R. 2012. Novos registros de samambaias para a Amazônia Brasileira. Rodriguésia. 63(4):1151-1155.

GÓES-NETO, L.A.A. \& PIETROBOM, M.R. 2014. Cyatheales (Polypodiopsida) do Corredor de Biodiversidade do Norte do Pará, Brasil. Hoehnea. 41(3):401-409.

JESUS, R.M.DE, MENANDRO, M.S. \& THIBAU, C.E. 1986. Manejo florestal em Buriticupu. Anais $1^{\circ}$ Simpósio do Trópico Úmido. 1(1):245-251.

KÖPPEN, W.P. 1948. Climatologia: con un estudio de los climas de la tierra. Fondo de Cultura Econômica, México.

KESSLER, M. \& SMITH, A.R. 2017. Prodromus of a fern flora for Bolivia. I. General introduction and key to families. Phytotaxa. 327(1):057-089.

LATORRE, N.S., ARAGÃO, L.E.O.C., ANDERSON, L.O., ANDERE, L., DUARTE, V., ARAI, E. \& LIMA, A. 2017. IMPACTOS DE QUEIMADAS SOBRE DIFERENTES TIPOS DE COBERTURA DA TERRA NO LESTE DAAMAZÔNIA LEGAL BRASILEIRA. Revista Brasileira de Cartografia. 69(1):179-192.

LELLINGER, D.B. 2002. A modern multilingual glossary for taxonomic pteridology 3. American Fern Society, Washington, D.C. p. 263

MACIEL, S. 2016. Nephrolepis (Lomariopsidaceae - Polypodiopsida) na Amazônia brasileira. Rodriguésia. 67(1):077-084.

MACIEL, S. \& PIETROBOM, M.R. 2010a. Dryopteridaceae e Lomariopsidaceae (Polypodiopsida) do Campo Experimental da Embrapa Amazônia Oriental, Moju, Pará, Brasil. Rodriguésia. 61(3):405-414.

MACIEL, S. \& PIETROBOM, M.R. 2010b. Pteridaceae (Polypodiopsida) do Campo Experimental da Embrapa Amazônia Oriental, município de Moju, estado do Pará, Brasil. Acta Bot. Bras. 24(1):12-23.

MARTINS, M.B. \& OLIVEIRA, T.G. 2011. Amazônia Maranhense: Diversidade e Conservação. Belém.

MEHLTRETER, K. 2008. Phenology and habitat specificity of tropical ferns. In: Biology and Evolution of Ferns and Licophytes (RANKER, T.A. \& HAUFLER, C.H. (Eds.). New York: Cambridge University Press. p. 201221.

MIRANDA, M.V.C., GUIMARÃES, T.F.P.L., ADAMI, M., NARVAES, I.S. \& GOMES, A.R. 2017. Mapeamento e monitoramento de cicatrizes de queimadas na REBIO do Gurupi-MA utilizando imagens orbitais de média resolução espacial. In Anais do XVIII Simpósio Brasileiro de Sensoriamento Remoto - SBSR (D.F.M. Gherardi \& L.E.O.C. Aragão, coord.). Instituto Nacional de Pesquisas Espaciais, Santos, p. 6617-6624.

MIRANDA, C.V. \& SCHWARTSBURD, P.B. 2016. Aquatic Ferns from Viçosa (MG, Brasil): Salviniales (Filicopsida; Tracheophyta). Brazilian Journal of Botany. 39(3):935-942.

MOURA, L.C., ARRUDA, A.J. \& SALINO, A. 2016. Flora das cangas da Serra dos Carajás, Pará, Brasil: Thelypteridaceae. Rodriguésia. 67(5):1181-1189.

ØLLGAARD, B. \& WINDISCH, P.G. 2016. Lycopodiaceae in Brazil. Conspectus of the Family II. The genera Lycopodiella, Palhinhaea, and Pseudolycopodiella. Rodriguésia. 67(3):691-719.

PIETROBOM, M.R. \& BARROS, I.C.L. 2002. PTERIDÓFITAS DE UM REMANESCENTE DE FLORESTA ATLÂNTICA EM SÃO VICENTE FÉRRER, PERNAMBUCO, BRASIL: PTERIDACEAE. Acta Bot. Bras. 16(4):457-479.

PPG I. 2016. A community-derived classification for extant lycophytes and ferns. Journal of Systematics and Evolution, Beijing. 54(6): 563-603.

PRADO, J., HIRAI, R., MORAN, R.C. 2017. Fern and lycophyte flora of Acre state, Brazil. Biota Neotropica. 17(4): e20170369. http://dx.doi org/10.1590/1676-0611-BN-2017-0369

PRYER, K.M., SCHUETTPELZ, E., WOLF, P.G., SCHNEIDER, H., SMITH, A.R. \& CRANFILL, R. 2004. Phylogeny and Evolution of Ferns (Monilophytes) with a focus on the early leptosporangiate divergences. American Journal of Botany. 91(10): 1582-1598. 
Silva Junior WR, et al.

RODRIGUES, T.C.S. 2018. Estudo da cobertura e uso da terra na microrregião do Gurupi, Amazônia maranhense, entre os anos 1976 - 2016 por meio da aplicação do sensoriamento remoto e SIG's. Tese de doutorado, Universidade Estadual Paulista "Júlio de Mesquita Filho", São Paulo.

ROLIM, S.G., NASCIMENTO, H.E.M. \& ASSUNCC̃̃O, P.A. 2011. Estrutura da Floresta Ombrófila na Serra do Tiracambu, Amazônia Maranhense. In: Fitossociologia no Brasil: Métodos e Estudos de Caso (FELFILI, J.M.; EISENLOHR, P.; MELO, M.F.; LEONARDO, A. \& MEIRA-NETO, J.A.A). Viçosa; UFV, p. 441-549.

SALINO, A., ARRUDA, A.J. \& ALMEIDA, T.E. 2018. Ferns and lycophytes from Serra dos Carajás, an Eastern Amazonian mountain range. Rodriguésia 69(3):1417-1434.

SALINO, A., FERNANDES, R.S. \& PIETROBOM, M.R. 2011. Thelypteris amazonica sp. nov. (Thelypteridaceae) from Amazonian Brazil. Nordic Journal of Botany. 29:611-614.

SAMPAIO, A.F., SOUZA, M.G.C. \& PIETROBOM, M.R. 2015. Samambaias e licófitas da Bacia Petrolífera de Urucu, Coari, Amazonas, Brasil. Acta Biológica Catarinense. 2(2):33-48.

SANTOS, O.C.O. 2014. A geografia física e as bacias hidrográficas na Amazônia. Revista GeoAmazônia. 1(2):17-27.

SILVA, A.T. 1989. Pteridófitas. In: Técnicas de coleta, preservação e herborização de material botânico (BONONI, V.L.R. \& FIDALGO, O (eds.). Instituto de Botânica; São Paulo, p. 33-34.

SILVA, J.M, RYLANDS, A.B \& FONSECA, G.A.B. 2005. O destino das áreas de endemismo na Amazônia. Megadiversidade. 1(1):124-131.

SILVA, M.R.P. \& ROSÁRIO, S.M. 2008. Licófitas e monilófitas (Pteridophyta) da Floresta Nacional de Caxiuanã, estado do Pará, Brasil: chave para as famílias e as espécies de Aspleniaceae e Blechnaceae. Bol. Mus. Para. Emílio Goeldi. Ciências Naturais. 3(2):151-163.
SILVA, G.S., SILVA, D.L.S., OLIVEIRA, R.R. \& CONCEIÇÃO, G.M. 2017. Licófitas e Samambaias no Cerrado do Leste do Maranhão, Brasil. Acta Brasiliensis. 1(2):13-16.

SILVA JUNIOR, W.R., FERNANDES, R.S. \& FERREIRA, A.W.C. 2018. First record of the exotic fern Pteris tripartita Sw. (Pteridaceae) for the Maranhão state, northeastern Brazil. Biodiversity International Journal. 2(2):161-163.

SPECIESLINK. (http://www.splink.org.br). (último acesso em 20/11/2019).

SPINELLI-ARAÚJO, L., BAYMA-SILVA, G., TORRESAN, F.E., VICTORIA, D., VICENTE, L.E., BOLFE, E.L. \& MANZATTO, C. 2016. Conservação da Biodiversidade do Estado do Maranhão: Cenário Atual em Dados Geoespaciais. Jaguariúna, Embrapa Meio Ambiente.

TEIXEIRA, G. \& PIETROBOM, M.R. 2015. Hymenophyllaceae (Polypodiopsida) na Mesorregião Metropolitana de Belém, Estado do Pará, Brasil. Rodriguésia. 66(3):807-827.

THIERS, B. 2019. (http://sweetgum.nybg.org/science/ih/). (último acesso em 20/11/2019)

XAVIER, S.R.S. \& BARROS, I.C.L. 2005. Pteridoflora e seus aspectos ecológicos ocorrentes no Parque Ecológico João Vasconcelos Sobrinho, Caruaru, PE, Brasil. Acta Botânica Brasílica. 19(4):775-781.

ZUQUIM, G., COSTA, F.R.C., PRADO, J. \& TUOMISTO, H. 2008. Guia de Samambaias e Licófitas da REBIO Uatumã. Manaus: Attema. p. 320.

Received: 05/02/2020

Revised: 05/06/2020

Accepted: $17 / 06 / 2020$

Published online: 15/07/2020 